AGRICULTURE AND BIOLOGY JOURNAL OF NORTH AMERICA

ISSN Print: 2151-7517, ISSN Online: 2151-7525, doi:10.5251/abjna.2011.2.11.1368.1374

(C) 2011, ScienceHuß, http://www.scihub.org/ABJNA

\title{
Egg laying and egg laying behavior of Red Palm Weevil, Rhynchophorus ferrugineus (Olivier) 1790 (Coleoptera: Curculionidae)
}

\author{
Sahin Ince ${ }^{1^{*}} ;$ F. Porcelli ${ }^{2}$ and I. Al-Jboory ${ }^{3}$ \\ 1 Ph.D student, Universita degli studi della Basilicata and Istituto Agronomico Mediterraneo \\ di Bari,Italy \\ 2 Faculty of Agriculture, Universita degli studi di Bari,Italy \\ 3 University of Baghdad,College of Agriculture,Baghdad,Iraq \\ * Correspondance author: Tel (+39) 3272020577 \\ e-mail: suleymansahin.ince@unibas.it and shnnce@hotmail.com \\ ABSTRACT
}

\begin{abstract}
Red Palm Weevil is a key pest of palm trees worldwide. Various studies have been conducted on life history and behavior of RPW, however some key points in egg laying period is still missing. The purpose of this study was to investigate the egg-laying timing as a number of egg /day /female, time interval between egg laying event and the female bio-etiological needs while ovipositing. The study was carried out through recording the behavior of adults with PC-driven video cameras equipped with natural bright and artificial IR light source. RPW was collected and allowed to lay eggs on Phoenix canariensis petiole. The number of eggs per day is variable according to time and female age; the average number of eggs per event is 4.13. Moreover egg laying timing and the time of deposition are quite variable while eggs can be laid anytime during the day and night. The average egg-laying time was $54.52 \mathrm{sec}$. The observations showed that the females need to fly, feed and mate before egg laying process.
\end{abstract}

Keywords: Palm Pest, Phoenix canariensis, Red Palm Weevil, egg laying

\section{INTRODUCTION}

Date palms are adapted to areas having long dry summers, mild winters and it has a unique characteristic to thrive in desert and oasis (Swingle 1904). Phoenix canariensis is probably one of the most popular ornamental trees in the world, which is native habitat in the Canary Islands and it is widely cultivated in Mediterranean basin (Guerra 1994). Nowadays, RPW is spreading in the Mediterranean basin through $P$. dactylifera and $P$. canariensis. The red palm weevil (RPW), Rhynchophorus ferrugineus (Olivier) (Coleoptera: Curculionidae) is the most widely distributed palm pest, which is native to Southern hemisphere. Lefroy (1906) described this pest for the first time on coconut palm and it considered as a key pest on coconut palm Cocos nucifera (Nirula, 1956).

Abraham et al., (1998) was summarized the detailed symptoms and presence of $R$. ferrugineus attack on Palm trees. Presence of tunnels on the trunk and base of leaf petiole, (ii) oozing out of thick brownish fluid from the tunnels, (iii) appearance of chewed up plant tissue, with typical fermented odor around the orifice of tunnels, (iv) appearance of a dried offshoot mostly those emerging from the leaf bases, (v) chewing sounds by the grubs, (vi) breaking of the trunk or toppling infestation and (vii) fallen empty pupal cases.

Some researchers investigated the life cycle of RPW on artificial diets and date palm trunk pieces but not on fresh petioles. RPW adults lay their eggs singly in the petiole tissues by female's ovipositor (Lefroy 1906). Oviposition period is around 45 days (EPPO 2008). The maximum number of eggs laid by one female was 231 (Hutson 1922), however in a good conditions, female is able to lay up to 531 eggs during its life cycle (Wattanapongsiri 1966). Kaakeh et al., (1997) observed the life cycle of Red Palm Weevil on artificial diet and sugarcane he found significant differences between numbers off eggs laid per female per day and the average number of eggs were 2.1 and 3.0.

Several eggs can be laid at one time in a hole, but they are not in contact to each other. After eggs laying the hole is cemented over to protect the eggs (Murphy \& Briscoe 1999). Egg hatches after 2 to 5 days into whitish or yellowish legless larvae, which bore into the interior of the palm and chew through 
the soft tissue (Henry 1917; Urbano 2008), by peristaltic muscular movement (Capinera 2008). The larval period varies form 25 to 105 days (Wattanapongsiri 1966). Larvae can be found in different parts of the plant, in trunk, crown or in any parts of trunk, near growing point bases of petioles or one meter below the crown (EPPO 2008). When the larva becomes mature it starts to make a pupal case made of chewed fibers, and it remains a few days without feeding. The larvae are pupated inside the pupal case (Nirula 1956). Jaya et al., (2000) and Cabello (2006) reported that, larvae have a minimum of 7 instars before entering into pupal stage on sugarcane and artificial diet. The pupal duration was two weeks (Giblin-Davis et al., 1995), and the complete life cycle of RPW, egg to adult, takes approximately four to five months.

The objectives of this study are to determine various life parameters of Red Palm Weevil collected from the ornamental palm trees in Puglia Region in Italy. Specific objectives were to (i) estimate the number of eggs lay per female/ day, (ii) egg laying span, (iii) time between subsequent egg laying events, (iv) requirements needed for female egg-laying.

\section{MATERIAL AND METHODS}

Obtaining Leaf bases: In order to study egg laying, non infested palm trees were randomly chose in the province Bari, Italy. Petioles were obtained from 7-9 years old plants. Cutting was done first, removing the spines and second, dividing each sample into four pieces to take only rachis. At the end 65 pieces of clean rachis were prepared and numbered from 1 to 60 , and 5 considered as control numbered from $\mathrm{C} 1$ to C5. In order to preserve the samples from drying, mastic was smeared on both rachis sides and left for drying. (Fig.1).

Preparation of Experimental Area: A plastic cage (30x60x25cm), video camera, foam, cap screw, rachis $(30 \times 10 \mathrm{~cm})$ and a computer were prepared to conduct these trials. A computer software program called Lux Riot 1.7.5 was adjusted to the cameras and $\mathrm{Pc}$ to record up to 16 different couples at the same time.

Holes were made to insert the camera and for aeration. Leaf shape section was created on foam to fix the leaf on it. Then, the video camera was tightened to the plastic box with a cap screw and adjusted to get a very clear viewpoint. These boxes were placed side by side. In this way a number of boxes can be observed with different females egg laying behavior, and at the same time in different experimental area (Fig. 2). After that, the experiment was established in the screen house to have good natural conditions.

These trials were conducted in Apulia region, which is characterized by a Mediterranean climate with humid mild winter and hot dry summer. The annual average temperature ranges from 15 to $16^{\circ} \mathrm{C}$, with a maximum of $35^{\circ} \mathrm{C}$ recorded in July and a minimum one of $0^{\circ} \mathrm{C}$ recorded in January. For this reason experiment was started on July to reach at least $27^{\circ} \mathrm{C}$ for their activities. During this time, temperature was measured into the screen house and it was increased up to $40^{\circ} \mathrm{C}$ which has a key role for development of insect.

Screen house has an anti-insect net, which surrounds the area, and entrance had accessible through with double door. Inside screen house where experimental area was about $10 \mathrm{~m}^{3}$. Then, cottony net were surrounded around it (Fig. 3).

Collection of RPW Adults: RPW adults used in this study were collected originally from infested palm trees in four different areas in Puglia Region in Italy and kept in a box contains apple fruits as a food source.

Marking Adults with Colored Pens: The Rhynchophorus ferrugineus individually were marked with ten different colors. These colors provide a definite code for RPW differentiation (Fig. 4).

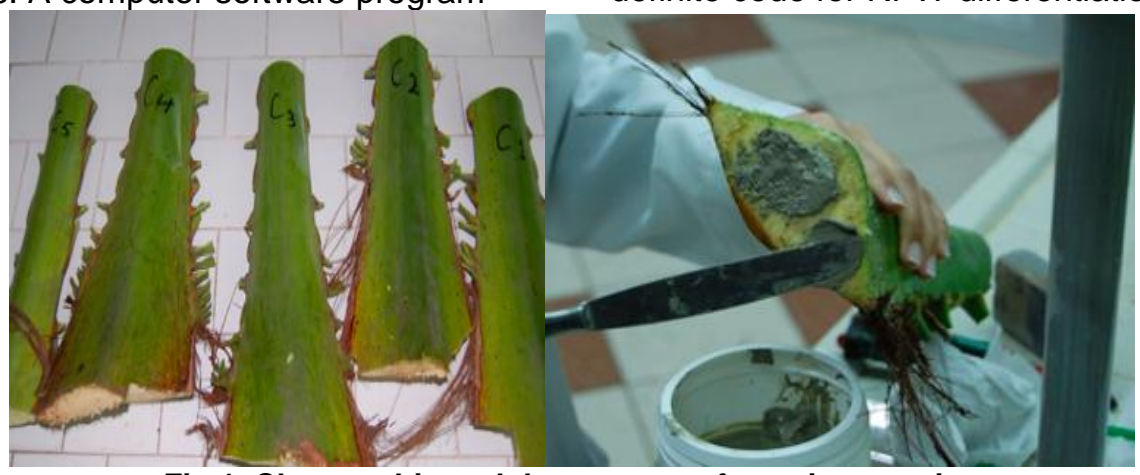

Fig 1. Clean rachis and the process of mastic smearing 
Agric. Biol. J. N. Am., 2011, 2(11): 1368-1374

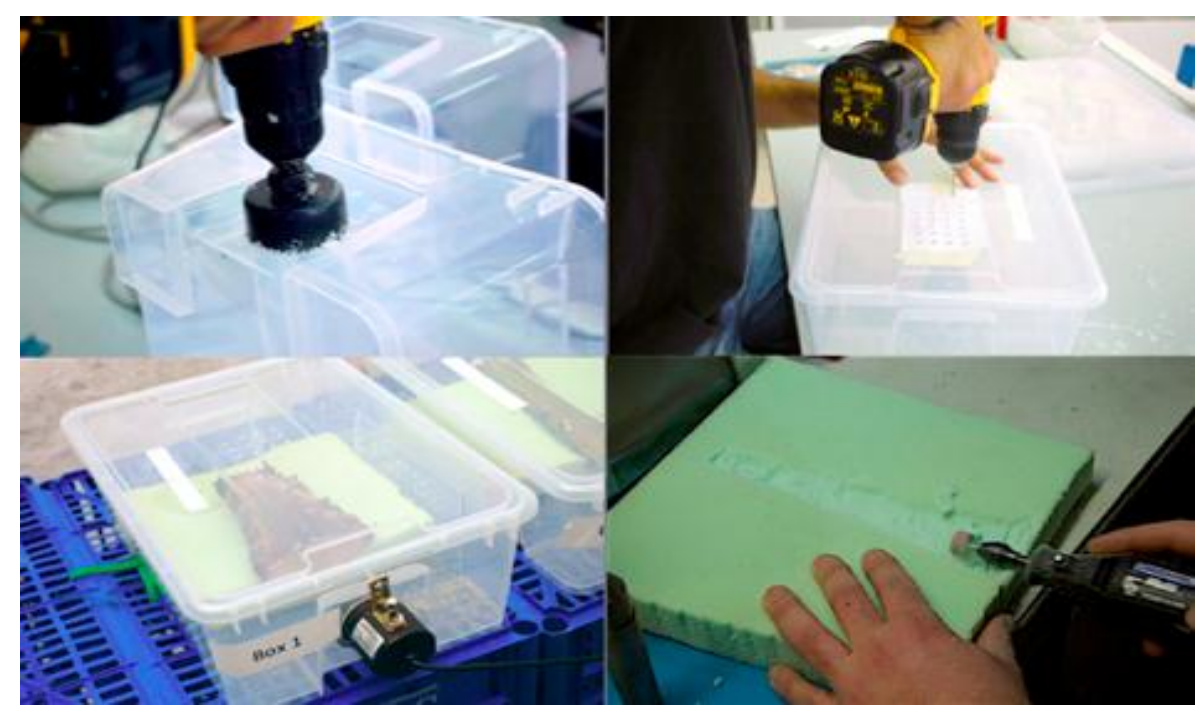

Fig 2. Preparation of experiment area

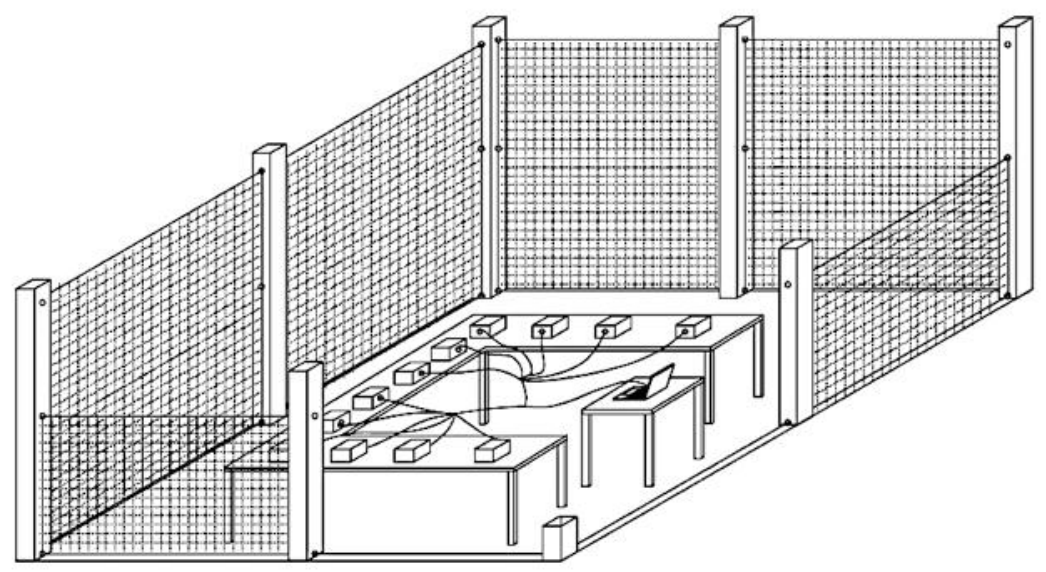

Fig 3. Connection of Pc-driven cameras inside the experiment area

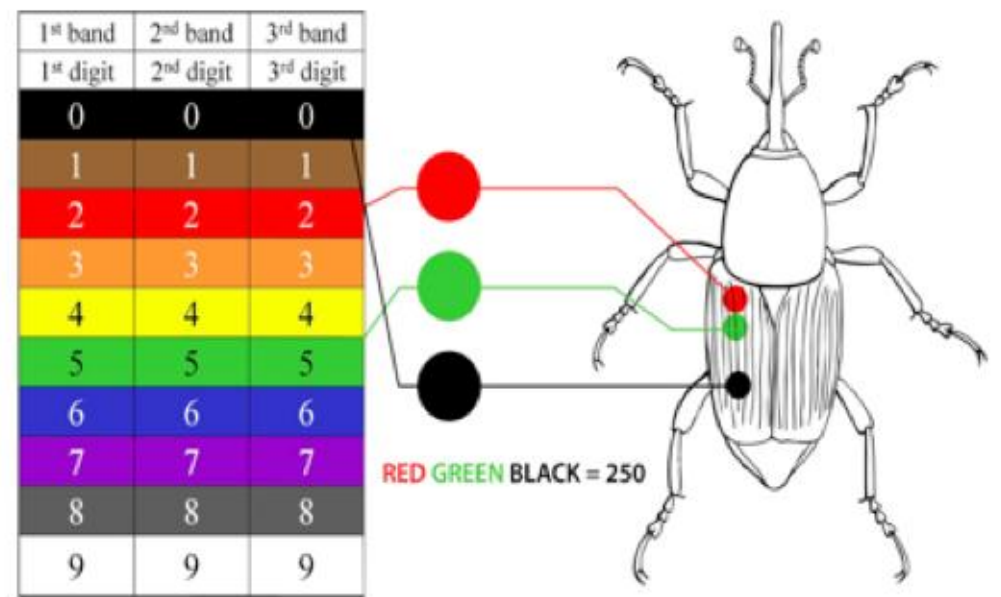

Fig 4. Marking with color bands (image taken by Mizzi et al., 2009) 
Agric. Biol. J. N. Am., 2011, 2(11): 1368-1374

\section{RESULTS}

Recording of adult behavior started the day after collecting of individuals, and cameras are set up at four frames per second (4 image per second). In order to observe egg laying during day and night in details all recordings lasted up to death of insect.

Number of Eggs Laid by Female per Day: The average number of eggs per female/day was 4.13 deposited by all experimented females on leaf bases as food source. The number of eggs per female were variable depends on time and female so some females lay up to 24 per day as shown in (Fig.5).

Egg laying span: Egg laying span was variable according to female. There were some exceptions like 10 or 150 seconds per female, but they mainly deposit eggs in 45 to 65 seconds. Also, the deposition time for each female was calculated and additionally, the average egg-laying span was 54.52 second for all studied females (Fig. 6).

Time laps between subsequent egg laying process: The deposition time was variable some females laid their egg during the day while the others at night. The time differences between subsequent egg laying process was significantly different to each other thus RPW has no certain time for egg laying process. They are able to lay eggs during any time of the day or night however sometimes they lay more eggs during night. Figures 6,7 and 8 show the time laps between subsequent egg laying process.

Female needs related to egg-laying behavior: RPW females were very active during the night so the bulk of egg laying operation was occurred in this time and they are more active than males. Mating may occur anytime of the day and many times, it takes between 1 to $5 \mathrm{~min}$. Females feed many times immediately before egg laying then flying was also an important factor for adults.

Adults were using special drilling behavior they create a very small wound on palm tissue with their strong mandibles, after then they fix their snout and move it front and back to create a deep hole.

Many researchers mentioned that RPW close the egg-laying chamber with a material however in this research it is proved that this material secreted from the female ovipositor, having the same color as the palm tissue used to keep the egg safe from bioagents. In this way of behavior it is very difficult to find out where is the infested area.

Many factors are affecting this behavior of RPW such as temperature, humidity and light. During this experiment, these conditions were controlled to keep the habitat as natural as possible. In addition the age of females is important parameter for these studies. DISCUSSION

Estimate the egg-laying process and behavior of Red Palm Weevil is very important parameter to understand its life cycle. Different researchers studied the life cycle and the egg-laying behavior of $R$. ferrugineus on artificial diet, semi artificial and natural diets in controlled conditions in the laboratory under $27^{\circ} \mathrm{C}, 75 \% \mathrm{RH}$. (Wattanapongsiri 1966; Kaakeh et al., 1997; Salama \& Abdel-Razek, 2002; Kaakeh 2005; Shanina et al., 2009). They showed that the use of different diets have significant effect on female oviposition, longevity and fecundity. However the present investigation of Red Palm Weevil egg laying behavior was studied under natural conditions by using leaf bases as a food source without any additives. No laboratory conditions were controlled such as moisture, temperature or light duration.

According to the results achieved in this investigation the following points were concluded:

Female's ovary can prepare up to 7-8 eggs ready to be laid sequentially.

The deposition time is variable; eggs lay at any time during the day or night. The interval time between two-deposition times was variable from 5 minutes to 20h. The RPW prefer the fresh cut palm pieces for feeding and egg lying.

The average of egg laying timing is 54.52 second for all egg laying process

The average number of eggs per day is 4.13 .

Drilling for egg laying process usually takes from 4 to 8 minutes. However drilling for feeding takes always less than 3 min (Fig. 9).

Mating can occur anytime of the day and many times even during egg laying process, it is variable between 1 to $5 \mathrm{~min}$. 
Agric. Biol. J. N. Am., 2011, 2(11): 1368-1374

The Average number of eggs per day

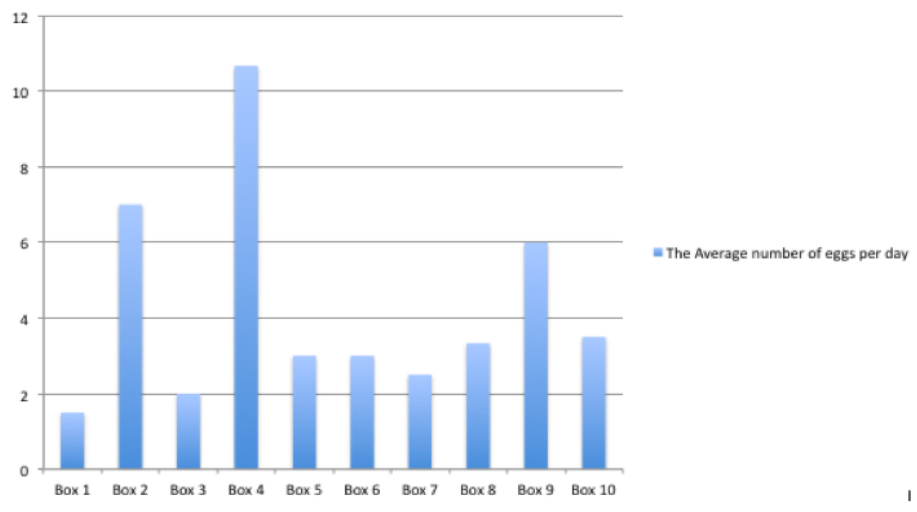

Fig 5. Average number of eggs per female

The average time for egg laying event for each box

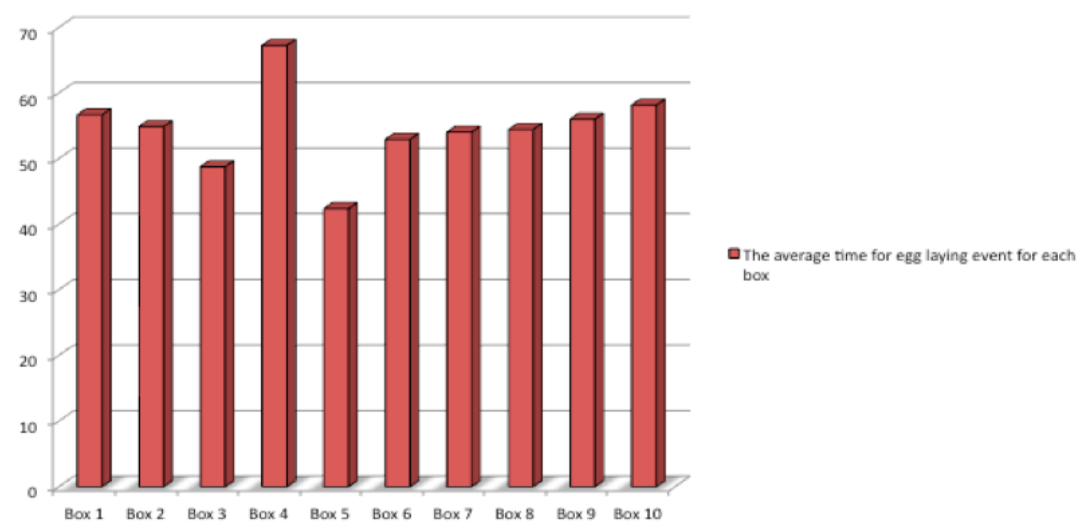

Fig 6.The average Egg laying span for each female
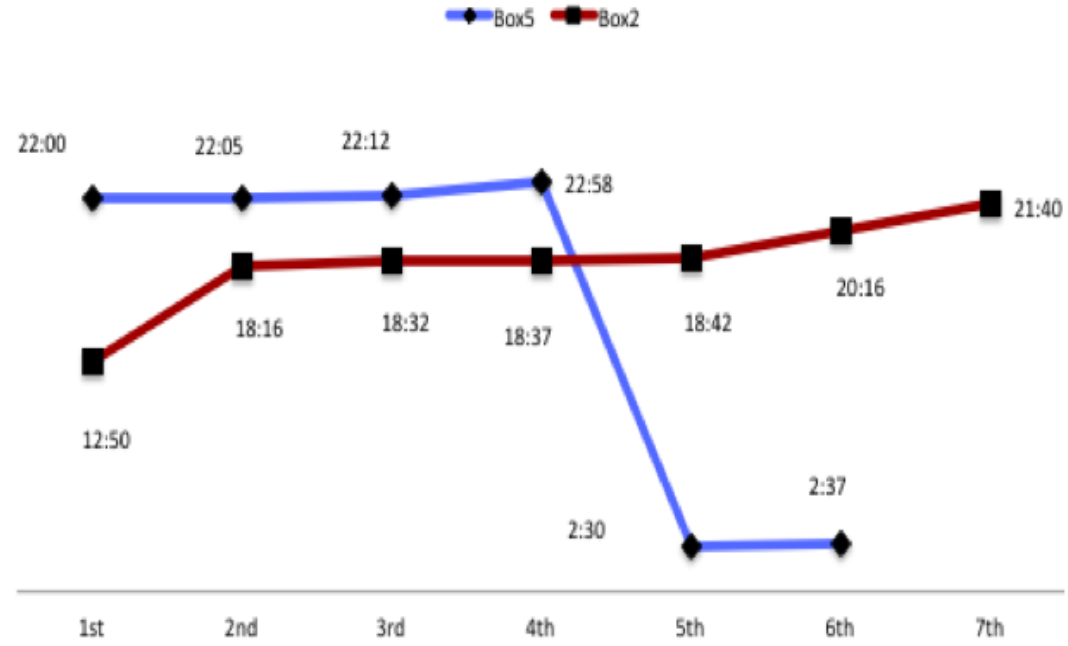

Fig 6. Interval time between each egg laying process for Box5 and Box2 
Agric. Biol. J. N. Am., 2011, 2(11): 1368-1374

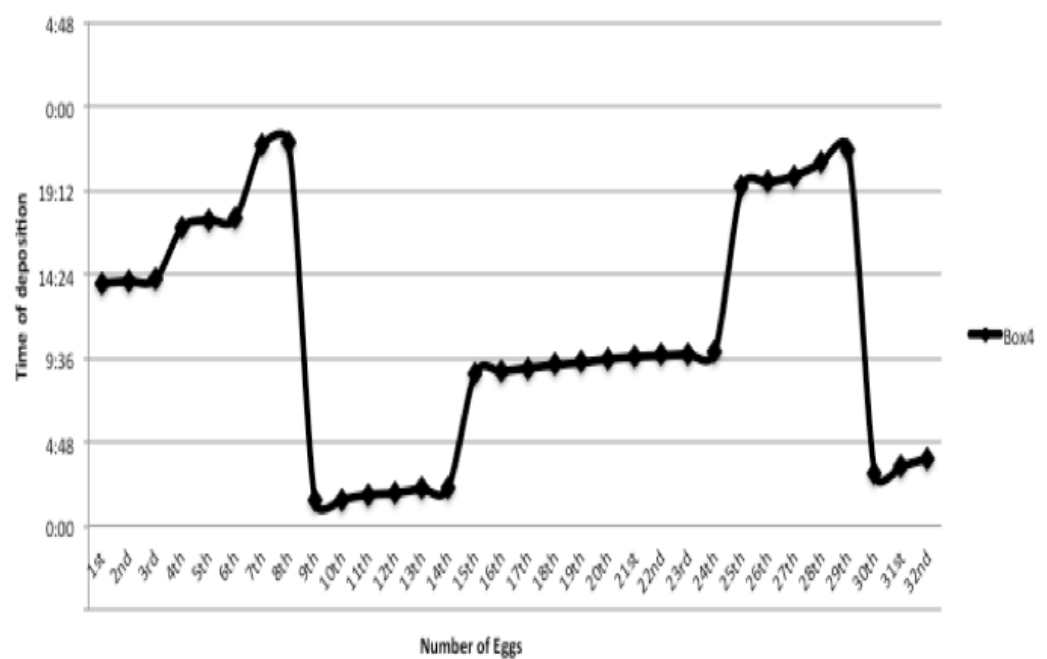

Fig 7. Egg laying interval in Box4 as a sample for another boxes

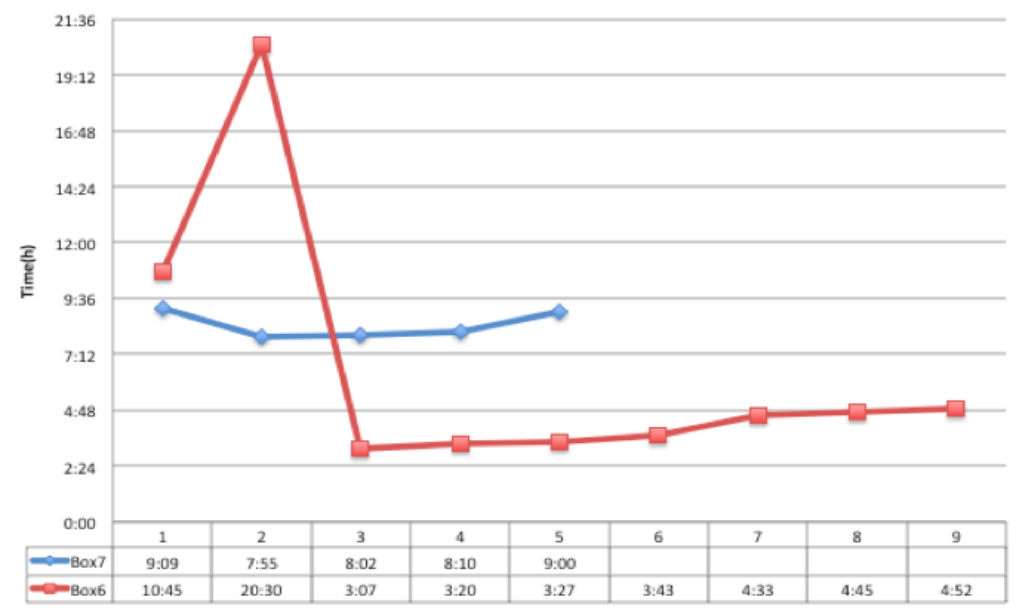

Fig 8. Female egg laying activity in Box6 and 7

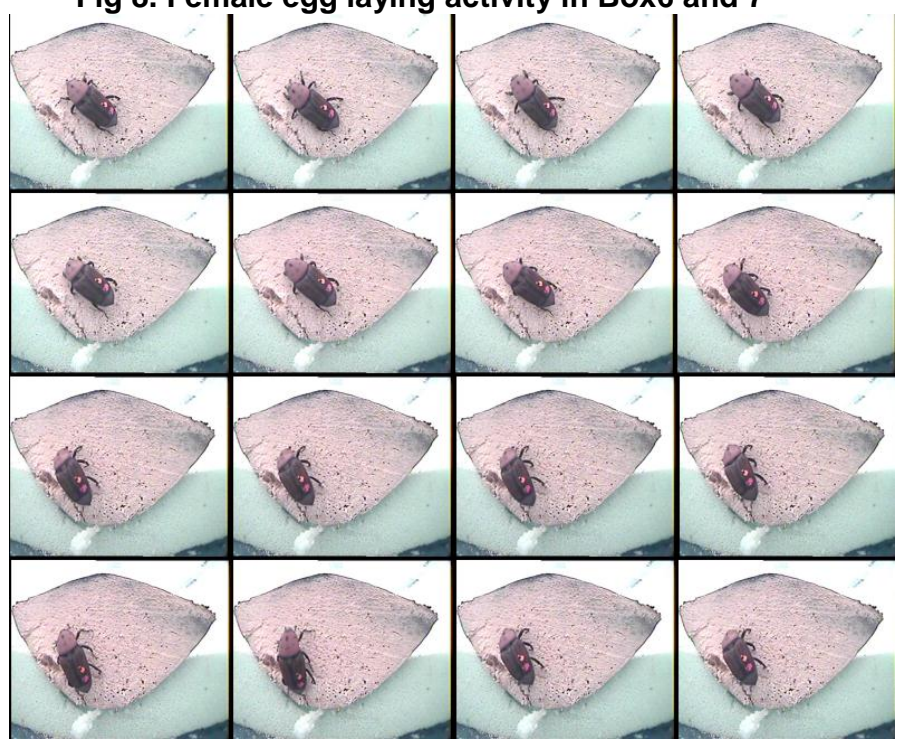

Fig 9. Drilling behavior of labeled Red Palm Weevil 


\section{REFERENCES}

Abraham, V.A.; Al Shuaibi, M.A.; Faleiro, J.R.; Abozuhairah, R.A.; Vidyasagar, P.S.P.V.; 1998 An Integrated Management Approach for Red Palm Weevil Rhynchophorus ferrugineus Oliv. a Key Pest of Date Palm in the Middle East. Sultan Qaboos University, Journal Science. Pest. Agricultural Science. 3: 77-84.

Cabello T. 2006. Population Biology and Dynamics of the Red Palm Weevil, Rhynchophorus ferrugineus (Olivier, 1790) (Coleoptera: Dryophthoridae) in Spain. Proceeding of the $1^{\text {st }}$ International Workshop on Red Palm Weevil, 28-29, November 2005, IVIA, Valencia, Spain (in press) 19-34. http://entomoagricola.files.wordpress.com/2007/04/cab ello2006biolecolrhyncho.pdf.

Capinera J.L. 2008. Encyclopedia of Entomology $2^{\text {nd }}$ Ed. Springer Science; ISBN: 978-1-4020-6242-1. 4346 pp.

Eppo. 2008. Data sheets on quarantine pests. Fiches in formatives sur les organismes de quarantaine Rhynchophorus ferrugineus. Bulletin OEPP/EPPO Bulletin. 38: 55-59.

Giblin-Davis R.M, Oehlschlager O.C, Perez, A, Gries G, Gries R, Weissling T.J.; Chinchilla C.M. Pena J.E. Hallett R.H. Pierce H.D, and Gonzalez L.M. 1995. Chemical and behavioral ecology of Palm Weevils (Curculionidae: Rhynchophorinae). Behavioral Ecology Symposium 95: 153-167.

Guerra A.S. 1994. Distribution of Phoenix canariensis in the Canary Islands. I International Symposium on Ornamental Palms. Acta Horticulturae 360, Ornamental Palms I. pp: 71-72.

Henry G.M. 1917. The coconut Red Weevil, Rhynchophorus ferrugineus. Tropical Agriculture, Peradeniya. XVIII (4): 218-219 (Abstract only).

Hutson J.C. 1922. The Red Weevil of Palm Weevil (Rhynchophorus Ferrugineus). Tropical Agriculturist. IX (4): 249-254.

Jaya S, Suresh T, Sobhitha Rani R.S, and Sreekumar S. 2000. Evidence of seven larval instars in the red palm weevil, Rhynchophorus ferrugineus Oliv. reared on sugarcane. J Ent. Res. 24(1): 27-31.
Kaakeh W. 2005. Longevity, fecundity, and fertility of the red palm weevil, Rynchophorus ferrugineus Olivier (Coleoptera: Curculionidae) on natural and artificial diets. Emir. J. Agric. Sci. 17 (1): 23-33. http://www.cfa.uaeu.ac.ae/Research/EJAS.htm

Kaakeh W, Aboul-Nour M.M, and Khamis A.A. 1997. Life parameters of the red palm weevil, Rhynchophorus ferrugineus Oliv., on sugarcane and on artificial diet. Faculty of Agricultural. UAE: 310-324.

www.pubhort.org/datepalm/datepalm2/datepalm2_37.pdf

Lefroy H.M. 1906. Indian Insect Pests. Office of the Superintendent of Government printing, India. 346 pp.

Mizzi S, Dandria D, Mifsud D, and Longo S. 2009. The Red Palm Weevil, Rhynchophorus ferrugineus (Olivier, 1790) in Malta (Coleoptera: Curculionoidea). Bulletin of the entomological Society of Malta. 2: 111-121.

Murphy S.T. and Briscoe B.R. 1999. The red palm weevil as an alien invasive: biology and the prospects for biological control as a component of IPM. Biocontrol News and Information. 20(1): 35-46.

Nirula K.K. 1956. Investigations on the pests of coconut palm. Part IV. Rhynchophorus ferrugineus F. Indian Coconut Journal. (9): 229-247.

Salama H.S and Abdel-Razek A.S. 2002. Development of the red palm weevil, Rhynchophorus ferrugineus (Olivier), (Coleoptera, Curculionidae) on natural and synthetic diets. J. Pest Science, ISSN 1436-5693. 75: 137- 139.

Shanina F, Salma J, Mehreen G and Bhatti M.I. 2009. Rearing of Rhynchophorus ferrugineus (Oliv.) in laboratory and field conditions for carrying out various efficacy studies using EPNs. Pak. Journal Nematol. 27 (2): 221-231.

Swingle W.T. 1904. The Date Palm and Its Utilization in the Southwestern States. Washington, Government Printing Office. 155 pp.

Urbano G. 2008. II punteruolo rosso delle palme: aspetti biologici e danni. Citta Nostra, Attualita. VII(63): 24-25.

Wattanapongsiri A. 1966. A revision of the genera Rhynchophorus and Dynamis (Coleoptera: Curculionidae). Department of Agriculture Science Bulletin. 418 pp. 